\title{
A Morphological and Anatomical Study on Endemic Campanula davisii Turrill ( Campanulaceae ) in Turkey
}

\author{
${ }^{*}$ Emine ALCITEPE ${ }^{1}$ \\ Manisa Celal Bayar University, Akhisar Vocational School, Manisa-Turkey \\ Tel: 9023641268 96-25 98 Fax:90 2364137058 \\ *Corresponding author: eminealcitepe@yahoo.com
}

Geliş Tarihi: 15.04 .2015

\begin{abstract}
Campanula davisii Turrill is an species endemic with a narrow distribution to Turkey and east Mediterranean Phytogeographic Region. The morphological and anatomical properties of this species were investigated. When morphological measurements of investigated species are compared with Flora of Turkey, the some differences have determined. Eventually, full description and illustration of these species was given. The anatomical studies on cross-sections of the root, stem, leaves and surface sections of leaves were presented. Cambium located under phloem was 2-3 layered and uncontinuous in root. Underneath the cortex parenchyma is endodermis, which consists of 1 layer and distinguishably in stem. Leaves is bifacial. Stomata are located both on the surface.
\end{abstract}

Keywords: Anatomy, Campanula davisii, Endemic, Morphology.

\section{Türkiye'de Yetişen Endemik Campanula davisii Turrill (Campanulaceae) Üzerine Morfolojik} ve Anatomik Bir Çalıșma

\section{Özet}

Campanula davisii Turrill Türkiye'de dar bir alana yayılmış endemik bir tür olup, Doğu Akdeniz Fitocoğrafik Bölge elementidir. Bu türün morfolojik ve anatomik özellikleri incelenmiştir. İncelenen türün morfolojik ölçümleri Türkiye Florası ile karşılaştırıldığında bazı farklar tespit edilmiştir. Çalışma sonucuna bu türün tam bir deskripsiyonu ve çizimi eklenmiştir. Kök, gövde, yaprak enine kesitleri ve yaprak yüzeysel kesitleri verilmiştir. Kökte floem altında 2-3 tabakalı ve sürekli olmayan kambiyum bulunur. Gövdede korteks parankiması altında bir sıralı ve belirgin olarak ayırt edilebilen endodermis görülür. Yapraklar bifasialdir. Stoma her iki yüzeyde de yer alır.

Anahtar kelimeler: Anatomi, Campanula davisii, Endemik, Morfoloji.

\section{Introduction}

The genus Campanula L. is divided into 9 informal groups (designated A, B, C, D, E, F, G, $\mathrm{H}$ and I) in the Flora of Turkey. These are morphologically different from each other and have important lineaments. Group A [Sect. Quinqueloculares] is characterized by large and reflexed calyx appendages. Ovary is 5-locular. Stigma is 5. Capsule is opening by five basal pores. The taxa of the section are biannual or perennial herbs, usually monocarpic. Its stems are usually tall. All the species were endemic except from C. crispa Lam. (Damboldt, 1978). C. davisii Turrill has classified within in this group A and has endemic for Turkey.

The anatomy of taxa belonging to the family Campanulaceae is still inadequately known as emphasized by Damboldt (1976). Only a few anatomical studies on the genus Campanula $\mathrm{L}$. is reported in the literature (Uysal et al., 1984; Ocak and Tokur, 1996). There haven't been any published anatomical studies on the $C$. davisii Turrill. The pollen and seed characteristics of Sect. Quinqueloculares in Turkey previously have studied (Alçıtepe, 2010, 2012, 2013). Solving the problems of some taxonomic in this section, in addition to morphology and palynology, the anatomical features are also used (Alçıtepe and Yıldız, 2010; Alçıtepe, 2011).

So far, studies on the anatomy of the $C$. davisii Turrill haven't been reported in the literature. Therefore, the purpose of this paper is to investigate detailed morphologic and anatomic properties of $C$. davisii Turrill.

\section{Materials and Methods}

Examined specimens: Turkey: C4 Antalya: Isaurian Tauros, Ak Dagh, $10 \mathrm{~km} \mathrm{~S}$ of Geyik Dagh, 2000 m, 1947, Davis Foto K!, ibid. D., environmental of Beşkonak-Altınkaya village, 600 m, 12.06.1978, R. Çetik 6046, KNYA!; Gündoğmuş, vicinity of Belenyurt Plateau, high mountain steppe, calcareous slopes, $36^{\circ} 53^{\prime} 6^{\prime}$ ", North, 32 03' 8' 'East, 1540 m, 23.07.1998, A. Güner, 12587, GAZI!; Gazipaşa, Macarköyü Plateau, Sarımazı area, 1700-1800 m, 13.07.1982, H. Sümbül 26267, HUB!; Gündoğmuş, on calcareous rocks, 20.07.1983, $Y$ 
Gemici, G. Görk, Y. Arık 21923, EGE!; ibid. 8.07.2002, 2127; Geyik Mountain, Gündoğmuş Plateau, c. 1800 m, 23.07.1987, E. Leblebici, L. Bekat 31589, EGE!; Gündoğmuş, Geyik Mountain, Oğuz Plateau, clearence of Cedrus libani, 1500-1600 m, 13.07.1998, Başer 1387, GAZI! ibid. 09.07.2002, E. Alçıtepe 2128, ibid. 25.06.2009, E. Alçıtepe 2427; İçel : SilifkeGülnar road, South of Kayrak Mountain, on Korucuk ways, c. 100 m, 25.05.1951, H. Demiriz, 11208, ISTF!; Gülnar to Silifke 19 km, 1050 m, Hub.-Mor. 10200, ibid. 26.06.1981, M. Noydegger 16442, GAZI!; Anamur, Akine Village, Plateau of Elbalak nomad tent, 19002000 m, 20.06.1983, H. Sümbül 26029, HUB!; Anamur-Kazancı Highway, Unilalan area, 1400 m, 24.06.1984, H. Sümbül 26028 HUB!, Karaman: East of Ermenek, Hamitseydi Throut, 1500-1700 m, D. 16243; Ermenek-Kazanc1 Town, Kocaş location, Cedrus libani forest, 1500 m, 23.06.1984, H. Sümbül 26023, HUB! ibid.. 22.06.2002, E. Alçıtepe 2116, ibid. 02.08.2002, E. Alçıtepe 2130.

The plants were collected from different localities in Turkey between 2002 and 2009 (Figures 1,2). Samples that are found in EGE, GAZI, HUB, ISTF, KNYA herbariums were examined whereas the photographs of the type samples contained in $\mathrm{K}$ herbarium was taken. The materials that are necessary for anatomical studies were preserved in $70 \%$ alcohol and paraffin infiltrated tissues (Algan, 1981). The measurements were based on 30 readings from each specimen. The mean value of the measurements (M) and standart deviation (SD) were calculated. In addition, superficial sections of adaxial and abaxial sides of the leaves were taken.

\section{Results \\ Morphology}

Campanula davisii Turrill in Bot. Mag. 171: n.s.t.283 \& f.A-H (1956).

The biennual or perennial plant is branched and numerous stem. The erect-outspreading, slender stem is $7-28 \mathrm{~cm}$ tall. Surface of stem is covered by softly hirsute. Basal leaves are 0.7$0.9 \times 1.1-1.6 \mathrm{~cm}$. Shape of leaves are ovatecordate. The edge of leaves are dentate -serrate with $1.3-3 \mathrm{~cm}$ petiole. Lower cauline leaves are similar to basal and petiolate. Upper cauline leaves are sessile, ovate shape and dentate serrate. Flowers are in racemes, terminal or panicula and 3-31 mm pedicellate. Calyx is 5$8 \times 6-10 \mathrm{~mm}$. Calyx lobes are lanceolate, acuminate, equalling or $1 / 2$ longer than corolla tube. Calyx appendages is ovate, wholly concealing ovary and softly hirsute hairy. Corolla lobes are white or blue- lavander to blue- violet, corolla tube is cream coloured. Corolla is cylindrical shape, $5-9 \times 10-18 \mathrm{~mm}$, Corolla tube is (6) $10-15$ x 3-5 mm. Stigmas are 5. Ovary is 5locular. Pistil is $0.5-1 \times 9-10 \mathrm{~mm}$, stamen is 0.5 0.7x4-6 mm. Capsule is hirsute hairy. Seed is glabrous, elliptic to oblong or lanceolate in outline. Seed size is $0.25-0.4 \times 0.35-0.5 \mathrm{~mm}$. It is yellowish brown, dark brown to light-brown in colour (Figures 1, 2) (Table 1). Flowering occurs in June- August. Habitat is calcareous rocks, stony places, cliffs, (600)-1050-2000 m.

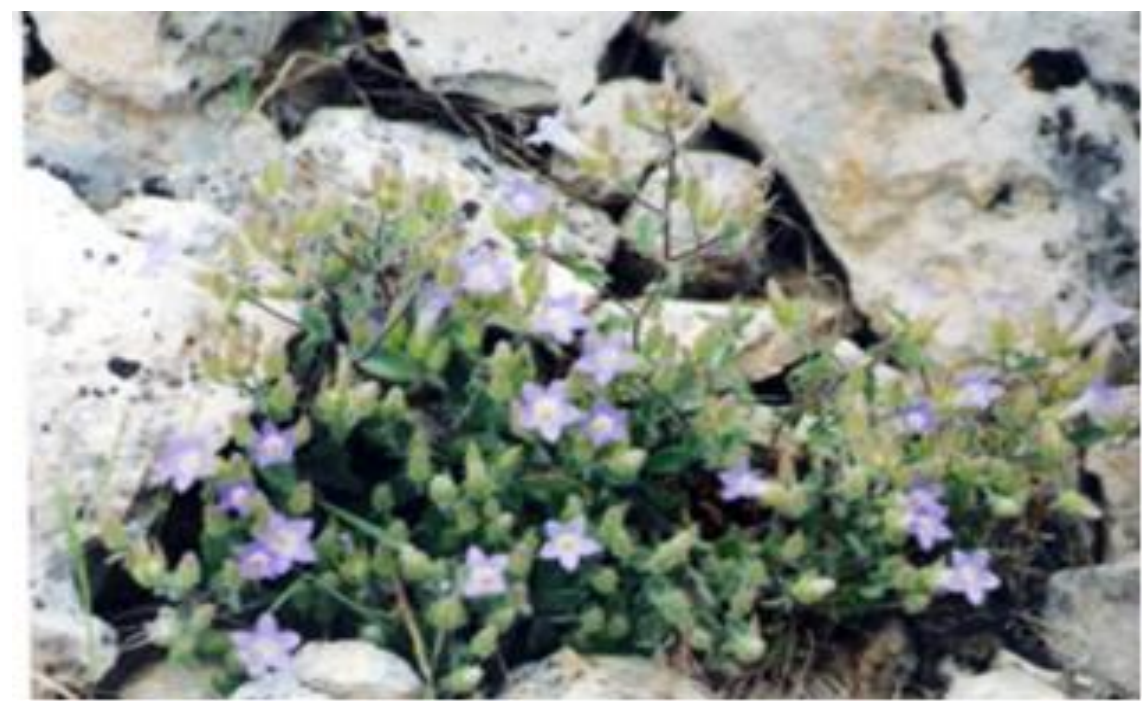

Figure 1. General appearance of C. davisii Turrill in natural habitat (Alçıtepe 2116) 


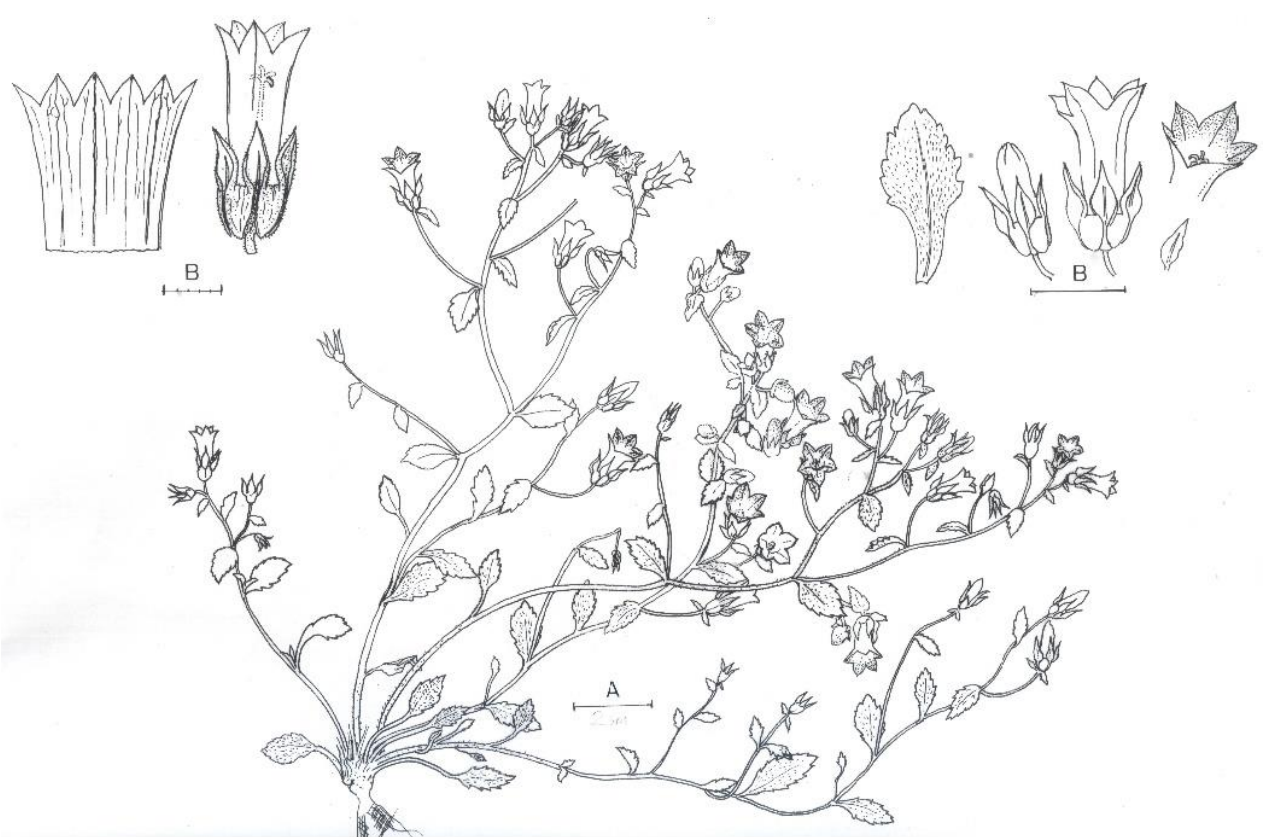

Figure 2. C. davisii Turrill A. Habit B. Corolla and calyx (bar: $2 \mathrm{~cm}$ ) (Alçıtepe 2116) Table 1. Comparative characters of $C$. davisii Turrill

\begin{tabular}{|c|c|c|c|c|c|c|}
\hline & \multicolumn{3}{|c|}{ Width } & \multicolumn{3}{|c|}{ Length } \\
\hline & $\min$. & $\max$. & $($ mean \pm ss $)$ & $\min$ & $\max$. & $($ mean \pm ss $)$ \\
\hline Root (cm) & 0.3 & 5.0 & $(1.23 \pm 0.90)$ & 1.2 & 17.0 & $(5.80 \pm 4.58)$ \\
\hline Stem $(\mathrm{cm})$ & 0.3 & 0.6 & $(0.47 \pm 0.12)$ & 7.0 & 28.0 & $(20.1 \pm 5.68)$ \\
\hline Lamina of basal leaves $(\mathrm{cm})$ & 0.7 & 0.9 & $(0.79 \pm 0.08)$ & 1.1 & 1.60 & $(1.43 \pm 0.15)$ \\
\hline Petiole of basal leaves $(\mathrm{cm})$ & 1.3 & 3.0 & $(2.24 \pm 0.54)$ & ---- & $\begin{array}{ll}--- \\
\end{array}$ & 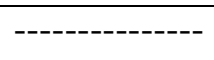 \\
\hline Pedicel $(\mathrm{mm})$ & ---- & $\overline{---}$ & 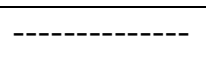 & 3.0 & 31.0 & $(14.4 \pm 7.37)$ \\
\hline Calyx (mm) & 5.0 & 8.0 & $(5.68 \pm 0.88)$ & 6.0 & 10.0 & $(8.72 \pm 1.40)$ \\
\hline Calyx lobe (mm) & 1.0 & 2.5 & $(1.84 \pm 0.32)$ & 5.0 & 10.0 & $(8.57 \pm 1.50)$ \\
\hline Corolla (mm) & 5.0 & 9.0 & $(7.0 \pm 1.11)$ & 10.0 & 18.0 & $(14.5 \pm 1.86)$ \\
\hline Corolla tube $(\mathrm{mm})$ & 3.0 & 5.0 & $(3.74 \pm 0.57)$ & 8.0 & 15.0 & $(11.51 \pm 1.31)$ \\
\hline Corolla lobes $(\mathrm{mm})$ & 1.5 & 4.0 & $(2.53 \pm 0.58)$ & 1.5 & 4.0 & $(2.72 \pm 0.76)$ \\
\hline Stamen $(\mathrm{mm})$ & 0.5 & 0.7 & $(0.6 \pm 0.10)$ & 4.0 & 6.0 & $(5.0 \pm 1.0)$ \\
\hline Pistil (mm) & 0.5 & 1.0 & $(0.81 \pm 0.20)$ & 9.0 & 10.0 & $(9.5 \pm 0.5)$ \\
\hline Seed (mm) & 0.25 & 0.4 & $(0.29 \pm 0.04)$ & 0.35 & 0.5 & $(0.43 \pm 0.06)$ \\
\hline
\end{tabular}


Stem: The stem was usually circular and had

\section{Anatomy}

Root: Peridermis was 3-5 layered in the root. Cortex parenchyma was 8-12 layered. Cambium located under phloem was 2-3 layered and discontinuous. Xylem was interrupted by parenchymatous large pith rays. Parenchymatous pith rays disintegrated at some areas. Trachea cells at seconder xylem were almost huge and became smaller through the pith region. Diameter of trachea cells was $16-48 \mu \mathrm{m}$. Pith region was small consisting of round shaped cells. In addition, primary xylem elements sometimes entered into the pith region (Figure 3).

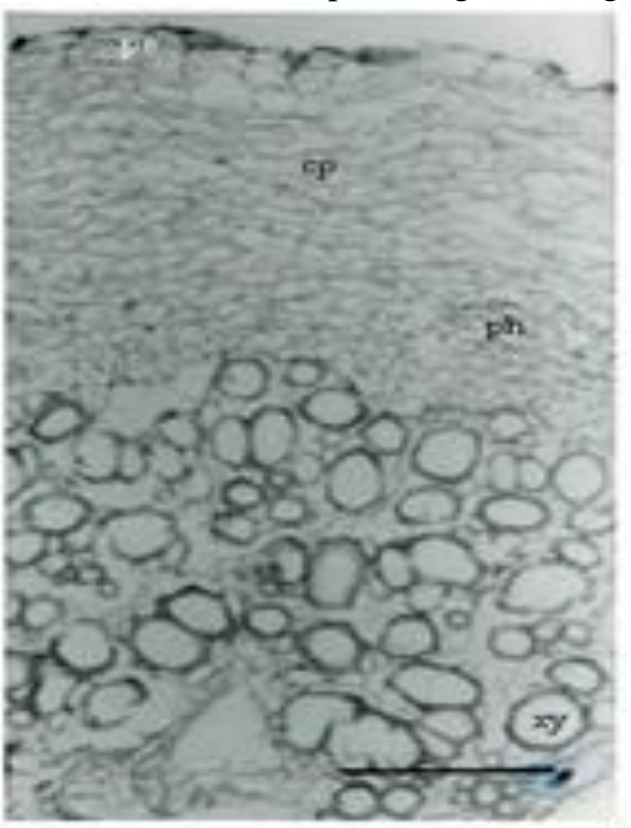

Figure 3. Cross-section of root $C$. davisii Turrill bar. $100 \mu \mathrm{m}$ pe: peridermis cell; cp: cortex parenchyma cell; ph: phloem; xy: xylem a lot of projections in places. The epidermis is composed of a single layer. The upper and lower walls of the epidermis are covered with a cuticle. The collenchyma tissue, located immediately under the epidermis. 2-3 layered cortex had intercellular spaces in the stem in the crosssections. Underneath the cortex parenchyma is endodermis, which consists of 1 layer and distinguishably. The pith consists of large hexagonal or polyhedral parenchymatous cells. Laticifer was distinguishable among the pith cells (Figure

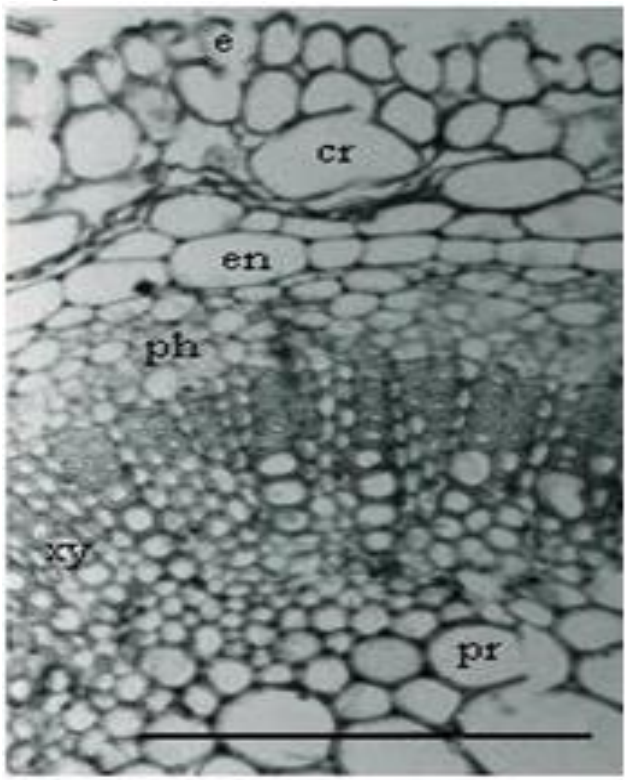

4).

Figure 4. Cross-section of stem C. davisii Turrill bar.100 $\mu \mathrm{m}$ e: epidermis cell; cr: cortex; en: endodermis cell; ph: phloem; xy: xylem; pr: pith cell

Table 2. Anatomical measurements of $C$. davisii Turrill

\begin{tabular}{|c|c|c|c|c|c|c|}
\hline & \multicolumn{3}{|c|}{ Width $(\mu \mathrm{m})$} & \multicolumn{3}{|c|}{ Length $(\mu \mathrm{m})$} \\
\hline & $\min$. & Max. & $($ mean \pm ss $)$ & $\min$. & $\max$. & $($ mean $\pm \mathrm{ss})$ \\
\hline
\end{tabular}

\begin{tabular}{lcccccc}
\hline Peridermis cell & 51 & 58 & $(53 \pm 1.52)$ & 11 & 26 & $(19 \pm 0.83$ \\
\hline $\begin{array}{l}\text { Cortex cell } \\
\text { Diameter of trachea } \\
\text { cell }\end{array}$ & 16 & 48 & $(34 \pm 1.84)$ & 11 & 21 & $\begin{array}{c}(16 \\
\pm 0.74)\end{array}$ \\
\hline Diameter of pith cell & 21 & 78 & $(35 \pm 0.90)$ & & & \\
\hline
\end{tabular}


Continuing Table 2.

\section{STEM}

\begin{tabular}{lcc}
\hline Epidermis cell & $16-21$ & $13-21$ \\
& $(18 \pm 0.25)$ & $(16 \pm 0.31)$ \\
\hline Cortex cell & $12-24$ & $11-21$ \\
& $(17 \pm 1.23)$ & $(16 \pm 1.07)$ \\
\hline Endodermis cell & $21-54$ & $21-32$ \\
& $(36 \pm 0.82)$ & $(25 \pm 0.39)$ \\
\hline Diameter of trachea & $11-32$ & \\
cell & $(22 \pm 1.36)$ & \\
\hline Diameter of pith cell & $21-85$ & \\
& $(56 \pm 3.61)$ &
\end{tabular}

LEAF

\begin{tabular}{lcccccc}
\hline Cuticle & 1 & 3 & & & & \\
\hline Upper epidermis cell & 21 & 48 & $(30 \pm 1.42$ & 16 & 32 & $(23 \pm 0.94)$ \\
\hline $\begin{array}{l}\text { Lower epidermis } \\
\text { cell }\end{array}$ & 11 & 34 & $(21 \pm 1.25)$ & 11 & 21 & $(16 \pm 0.73)$ \\
\hline $\begin{array}{l}\text { Palisad parenchyma } \\
\text { cell }\end{array}$ & 16 & 24 & $(19 \pm 0.55)$ & 42 & 53 & $(47 \pm 0.67)$ \\
\hline $\begin{array}{l}\text { Spongy parenchyma } \\
\text { cell }\end{array}$ & 16 & 21 & $(18 \pm 0.44)$ & 21 & 32 & $(26 \pm 0.70)$ \\
\hline
\end{tabular}

Table 3. Comparasion of morphological characteristic with Flora of Turkey

\begin{tabular}{lll}
\hline & Results of this study & Flora of Turkey \\
\hline Stem & up to $28 \mathrm{~cm}$ & up to $25 \mathrm{~cm}$ \\
\hline Basal leaves(with petiolate) & c. $4.6 \mathrm{~cm}$ & c. $6.5 \mathrm{~cm}$ \\
\hline Calyx lobes & $\begin{array}{l}\text { up to } 1 / 2 \text { corolla tube or more } \\
\text { longer }\end{array}$ & up to $1 / 2$ corolla tube \\
\hline Corolla tube & (6) $10-15 \times 3-5 \mathrm{~mm}$ & (8) $10-15 \times 4 \mathrm{~mm}$ \\
\hline
\end{tabular}

Leaf: Leaves contains a thin cuticle both upper and lower epidermis in the cross-sections. The adaxial epidermis cells $(21-48 \times 16-32 \mu \mathrm{m})$ are larger than abaxials (11-34x11-21 $\mu \mathrm{m})$. Epidermal cells are covered with simple eglandular trichomes. The leaf is bifacial. The palisade cells are usually 1-2 layered, cylindrical cells with intercellular space. Spongy parenchyma consists of 8-10 layers and there are usually intercellular spaces. Stomata type is amaryllis and anomocytic. It occurs on both surfaces (amphistomatic leaves). The cell walls of abaxial epidermis were more sinuous in contrast to the adaxials in the superficial sections (Figures 5-6). 


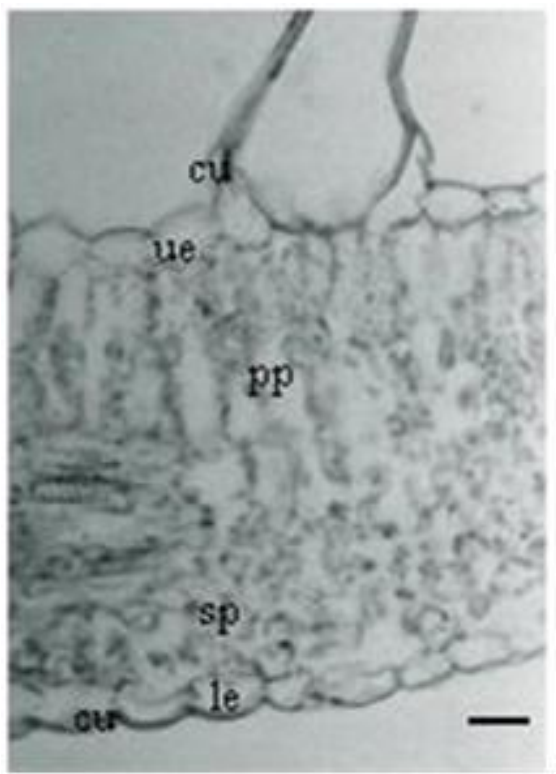

Figure 5. Cross-section of leaf $C$. davisii Turrill bar: $100 \mu \mathrm{m}$ cu: cuticle; ue: upper epidermis; pp: palisade parenchyma; sp: spongy parenchyma; le: lower epidermis

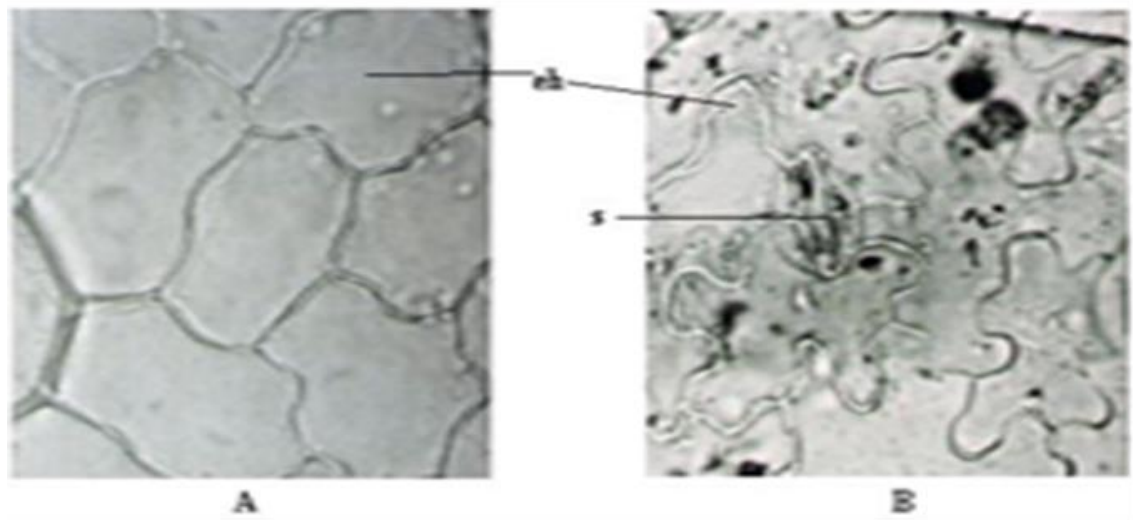

Figure 6. Leaf surface anatomy C. davisii Turrill A. Upper surface (10x40), B. Below surface (10x40), eh: epiderma cell, s: stoma cell

\section{Discussion}

In this paper, detailed morphological and anatomical structures of $C$. davisii Turrill belonging to sect. Quinqueloculares were examined. $C$. davisii Turrill is an species endemic with a narrow distribution to Turkey and east Mediterranean phytogeographic region elements. It is clearly separated from other species with the fact that corolla tube is cream, corolla lobes are blue in colour. Holotype was examined photographs where sent Herbarium of Kew (K). In our study, the morphological measurements were compared with Flora of Turkey. Some of differences in the characters were presented in the Table 3 . No numerical value was given except for stem length, basal leaves and corolla tube in the Flora of Turkey (Damboldt, 1978). This study have revealed all morphological characteristics that have taxonomical value with measurement in order to clarify their similarities and differences here for the first time. Another new findings are the morphological characteristics of seed concerning their shapes, sizes and colour of testa (Table 1).

The usual features of Campanulaceae anatomy (Metcalfe and Chalk, 1983) were observed in anatomical studies of the species. This taxon was covered by peridermis on the outer surfaces of root. Cambium was distinguishable but discontinuous (Figure 3). We did not observe any laticifer in the root of examined species, while the researchers observed laticifer in C. lyrata Lam. subsp. lyrata (Uysal et al. 1984). Pith occupied a small area and was interrupted by the xylem brunchs in the $C$. davisii. Endodermis was indistinguishable in the root of this species in our study in correspondance with the literature (Uysal et al., 1984; Ocak and Tokur, 1996). Endodermis in the stem of the examined species was circular, 
continous and consisting of large parenchymatous cells, surrounding the vascular bundles (Figure 4). We found laticifers located in the pith of stems in C. davisii Turrill, as stated by Metcalfe and Chalk (1983). The leaves were bifacial, consisting of palisade and spongy parenchyma in the cross-sections (Figure 5). The leaves were amphistomatical. Stoma type was amaryllis and anomocytic for this species. Stomata were present on both abaxial and adaxial epidermis. Same results have been reported by Ocak and Tokur (1996), Alçıtepe (2013). In the superficial sections (Figure 6), the cell walls of abaxial epidermis were more sinious, while those of the adaxials were closer to straight.

C. davisii Turrill has been previously reported in the LR (cd) category (Lower risk-conservation dependent) (Ekim et al., 2000; IUCN, 2001).

\section{Acknowledgements}

The research work is based on part of Ph.D thesis of Emine Alçitepe submitted to the Celal Bayar University (Project Number: 2002/91). It were presented at the Mersin Symposium (18-22 Kasim 2008) but not published (The morphological, anatomical and palynological study endemic Campanula davisii Turrill).

\section{References}

Alçitepe E. 2010. Studies On Seed Morphology of Campanula L. Section Quinqueloculares (Boiss.) Phitos (Campanulaceae) in Turkey, Pak. J. Bot., 42(2): 1075-1082.

Alçıtepe E., Yıldız K. 2010. Taxonomy of Campanula tomentosa Lam. Campanula vardariana Bocquet From Turkey, Turk. J. Bot., 34: 191-200.
Alçıtepe E. 2011. New Combinations in Campanula L. Sect. Quinqueloculares from Turkey, Pak. J. Bot., 43(5): 2243-2254.

Alçıtepe E. 2012. Comparative Pollen Morphology of Sect. Quinqueloculares (Campanulaceae) in Turkey, Biologia, 67/5: 875-882. Alçıtepe E. 2013. Campanula crispa Lam. Türünün (Campanulaceae) Morfolojik ve Anatomik Özellikleri, Ot Sistematik Botanik Dergisi, 20 (2): 27 40.

Algan G. 1981. Bitkisel Dokular İçin Mikroteknik, Frrat Univ. Fen Fak. Yay. Bot. No I, İstanbul.

Damboldt J. 1976. Materials for a flora of Turkey XXXII: Campanulaceae. Notes from the R.B.G. Edinb. Vol. 35:39 - 52.

Damboldt J. 1978. Campanula L. In Davis P.H. (ed.) Flora of Turkey and the East Aegean Islands. Edinburgh Univ Press Vol. 6, Edinburgh.

Ekim T., Koyuncu M., Vural M., Duman H., Aytaç Z., Adıgüzel N. 2000. Türkiye Bitkileri Kırmızı Kitabı (Eğrelti ve Tohumlu Bitkiler), Red Data Book of Turkish Plants, Ankara.

IUCN Species Survival Commission 2001: IUCN red list categories and criteria. Approved by $51^{\text {st }}$ Meeting of the IUCN Council, Version 3.1, Gland, Switzerland.

Metcalfe C.R., Chalk L. 1983. Anatomy of the Dicotyledons. Vol. II. Clarendon Press, Oxford.

Uysal İ., Öztürk M., Pirdal M., Güvensen A. 1984. Campanula lyrata Lam. subsp. lyrata endemik taksonunun morfolojisi, anatomisi ve ekolojisi üzerinde bir çalışma, XII. Ulusal Biyoloji Kongresi, 247-251, Edirne.

Ocak A., Tokur S. 1996. Eskişehir ve çevresinde (B3) yayılış gösteren Campanula L. taksonları üzerinde anatomik çalışmalar, Tr. J. Bot., 20, 221 229. 